\title{
PENDIDIKAN SEKS PADA ANAK
}

\author{
Nurlaili \\ Fakultas Syariah dan Ilmu Hukum UIN Suska Riau \\ HP: 081365739941
}

\begin{abstract}
Basicly, the teaching of sex education for the child is the same as giving immunisation to him/her. The child who has got the sex education expected will has a high self control and impenetrability to the virus attack of sex unrighteous, for example pornography, deviation, or sex abused, so that the child is not easy to infects by irresponsible sex. The Sex education for the child conducted step by step as according to his/her age. Instruction of sex is conducted squarely, easy going, and does not with negative enragement to the problem of sex. Parents have to develop sportive communications, so that the child will has a emotional openness toward parents, growing up the child trust toward parents, The problems of sex are not only a problem of intimate relationship, but many problems are there, either biological, psychological, and social. In Islam, the sex education is a part of the integration of aqidah, moral, and religious education.
\end{abstract}

Kata Kunci: pendidikan seks, perilaku seks, penyalahgunaan seks, masalah seksual, dan seksualitas.

\section{PENDAHULUAN}

Hampir bisa dipastikan bahwa tidak akan ada orang tua yang merasa nyaman ketika harus mengajarkan seks kepada anaknya. Malu, risih dan sungkan adalah kumpulan perasaan yang pasti menyergap orang tua jika harus mentransfer pengetahuan seks pada anak. Perasaan ini masih ditambah pula dengan kecemasan orang tua yang kerap khawatir kalau anak yang mendapat informasi seks banyak terlalu dini, akan terdorong untuk buru-buru 
melakukannya. Dapat dipahami mengapa ini terjadi, karena masalah seks bagaikan pisau bermata dua. Di satu sisi bersifat sebagai pusat informasi tentang seksualitas, tapi di sisi lain dia seolah-olah bersifat justru sebagai pendorong anak untuk lebih tahu tentang seks, sehingga mendorongnya lebih jauh ingin mencoba. Apalagi bayangan orang tua biasanya bahwa masalah seksual adalah hanya seputar masalah 'hubungan intim'. Bayangan ini tentu sangat menakutkan bagi orang tua, guru, dan semua tokoh otoritas yang ada di sekeliling anak.

Secara umum, orang tua merasa sulit bersikap terbuka soal seks kepada anaknya karena merasa terintimidasi dengan pertanyaan anak. Disebabkan sikap mental orang tua dan orang-orang dewasa lainnya yang ada di sekeliling anak, anak 'tidak siap' untuk menghadapi keingintahuannya terhadap dirinya sendiri, terutama masalah seputar seksualitasnya. Perasaan ini muncul karena, pertama, tidak tahu jawaban yang pas untuk pertanyaan "seram" anak; kedua, tidak rela membayangkan anak yang masih polos sudah harus "dikotori" pembicaraan seks yang erotis; dan yang ketiga, takut jika diajarkan seks anak malah jadi terburu-buru ingin "mencicipinya"1.

Karena itu pulalah, di depan anak orang tua sering menunjukkan sikap tabu dengan mendiskreditkan seks sebagai aktivitas yang kotor dan menjijikkan. Padahal di belakang mereka, orang tua tak mampu menunjukkan euphoria terhadap seks lewat koleksi CD porno, majalah, obat kuat, dan lainlain. Industri seks tumbuh subur, dan orang tua adalah bagian dari komunitas dunia yang tergila-gila pada seks. Sikap munafik inilah yang dicontoh anak. Melalui pesan non verbal yang tanpa sadar orang tua kirimkan setiap hari, anak akan terbiasa melakukan aktivitas seks atau hal-hal yang berkaitan dengan penyalahgunaan seks di belakang orang tua. Sering kali orang tua mendengar dan terkejut dan shock ketika mendapati anak kesayangannya ternyata sudah aktif secara seksual tanpa sepengetahuan mereka.

Dari televisi atau surat kabar juga banyak diketahui bahwa seorang gadis dibunuh oleh sang pacar, karena terlibat konflik percintaan. Sementara orang tua tidak percaya, menyanggah dan menyatakan bahwa putri kesayangannya adalah gadis rumahan. Dan si orang tua menjadi tidak berkutik dan shock ketika hasil otopsi menyatakan ada janin di rahim anak gadisnya. Atau seorang anak yang tiba-tiba hamil, dan pada kenyataan yang menghamili adalah ayahnya atau ayah tirinya. Sementara ibunya tidak mengetahui kalau pelecehan itu terjadi berkali-kali yang dilakukan oleh sang ayah. Si anak mungkin saja menganggap bahwa ini adalah salah satu bentuk kasih sayang dari sang ayah. Hal-hal tersebut bisa terjadi, karena si anak tidak pernah tahu dan tidak mengerti tentang pelecehan seksual, tentang organ seksualnya, bagaimana memelihara dan menjaganya.

Banyak sekali kasus yang terjadi karena minimnya pengetahuan tentang masalah seksual. Tidak hanya kehamilan tak diinginkan, bahkan banyak kasus sekaliber pembunuhan, ternyata berawal dari penyalahgunaan seks. Misalnya saja kasus jagal jombang Ryan, yang ternyata titik ujung kasus mutilasi yang 
dilakukannya adalah masalah seks. Kasus-kasus tersebut menunjukkan kepada orang tua bahwa masalah seks bukanlah masalah yang sepele, karena itu jangan diabaikan.

Dan tidaklah pula bijaksana apabila orang tua menutup semua informasi tentang masalah seksual bagi proses pendidikan anak. Karena masalah seksual tidak hanya menyangkut hubungan intim, tetapi mencakup berbagai elemen seperti pemahaman alat kelamin secara biologis, fisiologis, dan fungsi hormonal, pemahaman gender dan seksualitas, pemahaman hasrat seksualitas, pemahaman komunikasi seksualitas, pemahaman sumber rangsangan seksualitas, pemahaman akil baligh, pemahaman seksualitas pada anak, remaja, dan usia lanjut, pemahaman hak pilih memiliki anak, pemahaman orientasi seksual, pemahaman industri seks, pemahaman penyimpangan seks, pemahaman terapi seks, pemahaman unsur genetis seksualitas, pemahaman kejahatan seksualitas dan hukumnya, pemahaman kebijakan publik berkaitan dengan aspek seksualitas masyarakat, dan masih banyak lagi yang lain. Menurut Dra. Dini Oktaufik ${ }^{2}$ pendidikan seks itu tidak selalu mengenai hubungan suami istri, tapi juga mencakup hal-hal lain seperti pemberian pemahaman tentang perkembangan fisik dan hormonal seorang anak serta memahami berbagai batasan sosial yang ada di masyarakat.

Sebagai orang tua, dan sekaligus guru pertama dan utama bagi anakanak, tetaplah lebih baik jika anak-anak merasa bebas bertanya kepada orang tua tentang apa saja yang ingin mereka ketahui tentang seks, karena itu menyangkut masalah dirinya sendiri, dan tumbuh kembang mereka, daripada mereka bertanya kepada orang lain, yang jawabannya belum tentu bertanggung jawab. Atau mereka mencari tahu sendiri melalui situs-situs di internet, VCD-VCD porno, Blue Film, dan lain sebagainya. Anak-anakpun tentunya lebih senang dan nyaman dengan orang tua yang lebih terbuka terhadap semua pertanyaan yang ditanyakan, dan ini artinya si anak bisa lebih komunikatif dengan orang tua terhadap semua persoalan yang dihadapinya. Dan orangtua haruslah bisa memberi jawaban yang proporsional, jujur, asertif, bertanggung jawab dan penuh arahan kepada si anak.

Dari berbagai fenomena di atas dapat dipahami bahwa masalah seks adalah masalah yang cukup urgen demi mempersiapkan anak menjadi anak yang dewasa dan matang dalam segala hal termasuk dewasa dalam menyikapi permasalahan seksual yang dihadapinya, sehingga tidak terjerumus ke dalam konflik seksual yang akan menghancurkan masa depannya. Karena itu, pada tulisan ini, diuraikan bagaimana cara orang tua mengajarkan tentang seks kepada anak dan juga berbagai permasalahan seksual yang sering muncul yang merupakan bagian dari pendidikan seksual pada anak.

\section{PEMBAHASAN}

\section{Masalah Seksual}

Pengertian seks dalam kamus bahasa Indonesia adalah jenis kelamin.

Dalam Kamus Oxford, seks adalah menyatakan tentang laki-laki atau 
perempuan dan seksual adalah hal-hal yang berhubungan dengan bagianbagian atau organ tubuh pada laki-laki atau perempuan ataupun perbedaan dan karakteristik laki-laki dan perempuan. Sedangkan masalah seksual adalam permasalahan yang menyangkut berbagai elemen tentang seksual seperti: pemahaman alat kelamin (alat reproduksi) secara biologis dan fisiologis, fungsi hormonal, pemahaman gender dan seksualitas, pemahaman hasrat seksual, pemahaman sumber rangsangan seksualitas, pemahaman seksualitas pada anak, remaja, dan usia lanjut, pemahaman industry seks, pemahaman penyimpangan seks, pemahaman unsur genetis, dan lain-lain sebagainya.

Pendidikan seks adalah upaya pengajaran, penyadaran, dan pemberian informasi tentang masalah seksual. Informasi yang diberikan di antaranya adalah pengetahuan tentang fungsi organ, reproduksi dengan menanamkan moral, etika, komitmen, dan agama, agar tidak terjadi penyalahgunaan organ reproduksi tersebut. Karena itu pendidikan seks dapat dikatakan sebagai cikal bakal pendidikan kehidupan berkeluarga yang memiliki makna sangat penting. Para ahli psikologi menganjurkan agar pendidikan seks mulai dikenalkan pada anak sejak usia dini, sesuai dengan tahap perkembangan kedewasaannya. ${ }^{3}$

Informasi tentang seks bisa diberikan sejak anak sudah bisa melakukan komunikasi dua arah. Orang tua saat ini perlu dibekali pengetahuan mengenai seks, karena tidak jarang juga anak-anak yang bertanya tentang masalah seks. Mencari informasi tentang seks, selain untuk menjawab pertanyaan anak, juga untuk mendidik anak sehingga dia mengetahui informasi yang tepat dan berguna. 4

Kurangnya pembekalan tentang seks membuat anak menjadi bingung dan bisa mencari informasi yang salah, sebab didapat dari narasumber yang tidak layak. Hasil akhirnya tentu tidak sesuai dengan harapan dan manfaat. Berikut ini akan di uraikan beberapa permasalahan seksual, di antaranya: perbedaan organ tubuh laki-laki dan perempuan, pemahaman alat kelamin dan hormon, pemahaman gender dan seksualitas, pemahaman hasrat dan sumber rangsangan seksualitas, penyimpangan seks, kekerasan seksual, dan masturbasi.

\section{Pemahaman Gender dan Seksualitas}

Gender secara umum digunakan untuk mengidentifikasi perbedaan lakilaki dengan perempuan dari segi social-budayanya. Sedangkan seks secara umum digunakan untuk mengidentifikasi perbedaan laki-laki dan perempuan dari segi anatomi biologi. Istilah seks yang berarti jenis kelamin lebih banyak berkonsentrasi kepada aspek biologi seseorang, meliputi perbedaan komposisi kimia dan hormone dalam tubuh, anatomi fisik, reproduksi dan karakteristik biologi lainnya. Sementara itu gender lebih banyak berkonsentrasi pada aspek social, budaya, psikologis, dan aspek-aspek non biologis lainnya.

Studi jender lebih menekankan perkembangan aspek maskulinitas atau feminitas seseorang, sedangkan studi seks menekankan perkembangan aspek biologis dan komposisi kimia dalam tubuh laki-laki dan perempuan. Untuk 
pertumbuhan anak menjadi seorang laki-laki atau menjadi seorang perempuan, lebih banyak digunakan istilah jender. Istilah seks umumnya digunakan untuk merujuk kepada persoalan reproduksi dan aktivitas seksual, selebihnya digunakan istilah jender. ${ }^{5}$

Ketika seorang anak dilahirkan, berdasarkan alat kelamin yang dimilikinya dapat dikenali apakah dia laki-laki atau perempuan. Jika dia mempunyai penis (alat mempunyai vagina (alat kelamin perempuan) maka ia dikonsepsikan sebagai anak perempuan. Ketika seorang anak dilahirkan, maka pada saat yang sama ia memperoleh tugas dan beban jender (gender assignment) dari lingkungan budaya masyarakatnya.

\section{Kekerasan Seksual}

Ada dua bentuk kekerasan seksual yang sering terjadi atau dialami oleh anak, yakni pelecehan seksual dan perkosaan.

\section{Pelecehan seksual}

Pelecehan seksual adalah segala bentuk perilaku yang berkonotasi seksual yang dilakukan secara sepihak dan tidak diharapkan oleh orang yang menjadi sasaran sehingga menimbulkan reaksi negatif seperti malu, marah, tersinggung, dan sebagainya pada diri si korban. Pelaku pelecehan seks pada anak biasanya orang yang dikenal baik anak di seorang tuarnya, bukan orang yang sama sekali asing. Bisa saja orang dari lingkungan keluarga, seperti kakek, ayah, paman, kakak kandung, pembantu, sopir, tukang kebun, dan lain-lain. Atau bisa juga dari lingkungan sekolah, seperti guru, teman, penjaga sekolah, atau dari tempat kursus atau orang seorang tuar rumah lainnya, seperti guru privat, pelatih kursus, atau teman sepermainan, tetangga sebelah rumah, dan lain-lain.

Untuk menghindari hal-hal yang demikian, anak harus diajari tatacara melindungi dirinya, membimbingnya untuk membedakan sentuhan kasih sayang dan sentuhan yang mengarah pada pelecehan. Anak harus dibiasakan untuk tidak mudah terbujuk dengan iming-iming apapun yang diberikan orang dewasa di seorang tuarnya. Mereka juga harus diajari untuk tidak takut mengatakan hal yang sebenarnya pada orang tua jika dia tidak merasa nyaman dengan sentuhan yang diterimanya dari seseorang. Tapi tidak dianjurkan menakut-nakuti anak karena anak mungkin akan keliru menafsirkan kedalam sikap frigid atau anti seks ketika mereka dewasa kelak.

Pada anak remaja, perlakuan yang tidak senonoh sering terjadi di tempat umum dan terbuka, misalnya kendaraan umum yang penuh sesak. Mereka sering menempel dan menggesek-gesekkan bagian depan tubuhnya (laki-laki) ke bagian belakang tubuh perempuan, mungkin di pundak atau di pantat, menyentuh, memegang, dan meraba pantat, dan payudara.

Untuk mengantisipasi hal yang demikian perlu kiranya orang tua mengingatkan remaja perempuan orang tua untuk selalu waspada ketika berada dalam situasi ramai dan penuh sesak, karena keramaian tersebut sangat 
disukai pelaku. Di samping itu, anak-anak hendaknya dibiasakan untuk ${ }^{6}$ : a) Berani dan bersikap tegas jika di dalam kendaraan umum mendapati dirinya menjadi objek pelecehan. Tidak pasrah, tapi melakukan perlawanan terhadap pelaku perbuatan tak senonoh itu, b) mengatur posisi ketika berjalan di tengah keramaian yang padat, dekap tas untuk menutupi dan melindungi payudara, c) Jangan takut untuk menjerit atau berteriak terhadap siapapun orang tak dikenal yang bersikap kurang ajar menyentuh dada, pantat, atau bagian-bagian tubuh anak di depan umum.

\section{Perkosaan}

Perkosaan adalah tindak kekerasan atau kejahatan seksual yang berupa hubungan seksual yang dilakukan oleh laki-laki terhadap perempuan dengan kondisi tidak atas kehendak dan persetujuan perempuan. Menurut KUHP (Pasal 285), perkosaan adalah kekerasan atau ancaman kekerasan, memaksa seorang perempuan bersetubuh dengan dia (laki-laki) di luar pernikahan. ${ }^{7}$

Maraknya perkosaan karena banyaknya tontonan pornografi ataupun bacaan-bacaan yang mempengaruhi perilaku seksual seseorang terutama lakilaki menjadi tidak mampu mengendalikan hasrat seksualnya. Akibatnya banyak terjadi pelecehan seksual dan perkosaan. Selain itu pemakaian obatobat terlarang juga bisa mendorong terjadinya tindak pemerkosaan.

Fenomena yang disayangkan sering terjadi yaitu perempuan korban dianggap sebagai pihak yang memicu terjadinya kasus perkosaan terhadap dirinya. Mereka bahkan mendapat sanksi sosial dari lingkungan di seorang tuarnya, misalnya dikeluarkan dari sekolah, dipandang hina, dikucilkan, dan lain-lain.

Untuk menangani kasus perkosaan tak perlu ragu untuk segera melaporkannya kepada polisi. Polisi akan mengantar korban ke dokter untuk divisum. Korban hendaknya diingatkan untuk tidak mandi, atau membersihkan diri sebelum diperiksa, karena sperma, serpihan kulit, ataupun rambut pelaku yang tertinggal di tubuh korban merupakan barang bukti yang sangat diperlukan untuk penyelidikan. Korban mestilah dibantu memahami bahwa dia adalah korban perkosaan, bukan penjahat atau orang yang bersalah.

Ada beberapa hal yang mungkin bisa disosialisasikan untuk menghindari anak perempuan dari tindak perkosaan, yaitu; a) bersikap tegas dengan menunjukkan sikap percaya diri, b) pandai membaca situasi, jika perasaan itu menyampaikan tanda-tanda yang tidak membuat nyaman dan waspada, maka percayai perasaan itu, c) hindari berjalan sendirian di tempat gelap dan sunyi, d) berpakaian yang sewajarnya dan tidak menghalangi gerakan, terutama sewaktu-waktu lari atau melakukan perlawanan jika diserang, e) sediakan peralatan untuk mempertahankan diri di dalam tas seperti deodorant semprot (untuk disemprotkan ke mata penyerang, atau payung berujung lancip, gunting kecil, cutter, dan lain-lainnya, f) jika pergi ke suatu tempat bawa dengan lengkap alamat, denah, berikut jalur kendaraan yang dibutuhkan agar tidak kelihatan seperti orang kebingungan. Jika harus 
mencari informasi tanyakan di tempat-tempat resmi, seperti pusat informasi atau mungkin di kantor polisi setempat, g) jangan mudah menumpang kendaraan orang yang belum dikenal, h) berhati-hati jika diberi minuman oleh seseorang, i) jangan mudah percaya pada orang yang mengajak bepergian atau menginap di suatu tempat yang belum dikenal, j) perbanyak pengetahuan dan sering membaca tulisan tentang pemerkosaan supaya dapat dipelajari tandatanda sipelaku dan modus operandi atau cara kerjanya, k) pastikan jendela, pintu kamar, pintu rumah, dan mobil, sudah terkunci dengan baik, l) belajar beladiri praktis untuk mempertahankan diri ketika diserang.

\section{Penyimpangan Seksual}

Penyimpangan seksual disebut juga deviasi seksual atau parafilia. Deviasi seksual artinya perilaku yang tidak biasa dilakukan, atau perilaku seksual yang dianggap bermasalah. Sedangkan parafilia berasal dari bahasa Yunani, yakni para artinya di luar kebiasaan, dan filia artinya cinta. Parafilia adalah suatu perilaku sosial yang menyimpang dari masyarakat umum

Penyimpangan seksual dapat disembuhkan melalui terapi yang kontinyu dengan mengunjungi psikolog atau psikiater, sehingga mendapatkan penanganan individual berdasarkan kasus yang dialaminya.

Ada beberapa bentuk penyimpangan seksual sebagai berikut; 1) Sadisme, yaitu seseorang yang mendapatkan kepuasan seks dengan terlebih dahulu menyiksa pasangannya dan sebaliknya yang disebut Masochis; 2) Exhibionisme, yaitu seseorang yang hanya bisa mendapatkan kepuasan seks dengan mempertontonkan kelaminnya di depan orang lain yang tidak ingin melihatnya; 3) Transexualist, yaitu seseorang yang secara kejiwaan merasa dirinya memiliki jenis kelamin yang berlawanan dari fisiknya, biasanya mereka menginginkan operasi ganti kelamin untuk penyesuaian identitas diri dengan orientasi seksualnya; 4) Voyeurism dan Scoptophilia, yaitu seseorang yang hanya bisa mendapatkan kepuasan seks dengan mengintip atau melihat orang telanjang. Misalnya mengintip orang senggama, baik melalui jendela atau lubang pintu (voyeurism) dan melihat gambar-gambar porno, blue film, pertunjukan persenggamaan dan lain-lainnya (scoptophilia); 5) Fetishisisme, yaitu menjadikan suatu benda sebagai objek seksualnya, misalnya pakaian dalam, rambut, sepatu, sarung tangan, dan lain-lain, biasanya dengan mengelus, memandangi, atau memakai benda-benda tersebut untuk melakukan masturbasi; 6) Pedophilia, seseorang yang mendapatkan kepuasan seks dengan melakukan hubungan seks dengan anak-anak; 7) Necrophilia, seseorang yang hanya bisa mendapatkan kepuasan seks dengan melihat mayat, atau berhubungan seks dengan mayat; 8) Skatologia telephone, percakapan cabul lewat telepon dengan orang dewasa yang tidak menginginkannya. Dan masih banyak lagi penyimpangan seksual yang lainnya.

\section{Penyimpangan Seksual pada Anak-anak}


Anak-anak selalu diliputi rasa ingin tahu, termasuk rasa ingin tahu terhadap organ tubuhnya. Salah satu bentuk keingintahuan yang merupakan penyimpangan seksual pada anak-anak adalah masturbasi. Masturbasi adalah semua cara self stimulation yang bisa mendatangkan perangsangan erotis. Kegiatan ini meliputi menyentuh atau merangsang bagian tubuh yang sensitif, seperti putting payudara, paha bagian dalam, klitoris dan vagina untuk perempuan, tuar kepala dan leher penis untuk laki-laki, baik dengan menggunakan alat ataupun tanpa alat dengan tujuan untuk mencapai kepuasan seksual. ${ }^{8}$

Masturbasi yang dilakukan oleh kanak-kanak muncul akibat dorongan rasa ingin tahunya terhadap keberadaan tubuh dan kelaminnya. Manipulasi genital sederhana yang dilakukan ternyata dianggap bisa mendatangkan sensasi baru yang mengasyikkan. Sama halnya dengan aktivitas makan cokelat, ice cream, atau hal lain yang mendatangkan kenikmatan dan keasyikan untuk terus melakukannya. Ini juga pertanda bahwa anak butuh aktivitas fisik lain yang lebih menyita enerji dan perhatiannya. Anak yang terlalu banyak menghabiskan waktu di depan televisi, atau anak yang kurang aktif bergerak, cenderung mengalihkan perhatiannya pada aktivitas seksual dengan melakukan eksplorasi genital. ${ }^{9}$

Dengan demikian, adalah keliru jika orang tua menunjukkan reaksi yang kasar dan negatif menanggapi perilaku normal ini. Tapi sungguh dapat dipahami jika kebanyakan orang tua merasa sangat kaget, shock dan bingung ketika mendapati anaknya melakukan aktivitas seks semacam masturbasi. Dan orang tua hendaknya waspada, karena kemungkinan anak yang mempunyai kecenderungan masturbasi dengan intensitas yang tinggi kemungkinan telah mengalami atau menjadi korban pelecehan seksual. Normal atau tidaknya masturbasi yang dilakukan dapat dilihat dari sejauhmana aktivitas tersebut menyita perhatian anak. Jika hanya sekedar memuaskan keingintahuannya maka ini bisa dikatakan normal. Tapi jika ia menghabiskan energi dan perhatiannya hanya untuk masturbasi dan enggan melakukan aktivitas lain, maka ini harus diwaspadai.

Kiat untuk menghindari hal ini adalah dengan memberikan anak banyak aktivitas untuk mengalihkan perhatiannya dan menyerap kelebihan energinya. Dengan demikian anak akan melupakan kegiatan masturbasinya. Orang tua tidak perlu marah, menasehati dengan berbagai hal, atau bersikap histeris melihat kanak-kanak masturbasi.

\section{Pendidikan Seks menurut Islam}

Pendidikan seksual dalam Islam merupakan bagian integral dari pendidikan aqidah, akhlak, dan ibadah. Pendidikan seksual tidak bisa lepas dari ketiga unsur tersebut, karena akan menyebabkan ketidakjelasan arah dari pendidikan seksual itu sendiri. Bahkan mungkin menyebabkan kesesatan dan penyimpangan tujuan semula. Pendidikan seksual yang terlepas dari unsur 
aqidah, akhlak, dan ibadah, hanya akan berdasar atas hawa nafsu manusia semata, dan mengumbar hawa nafsu adalah hal yang dilarang dalam Islam.

Dalam surah Al-Maidah ayat 49 Allah berfirman:

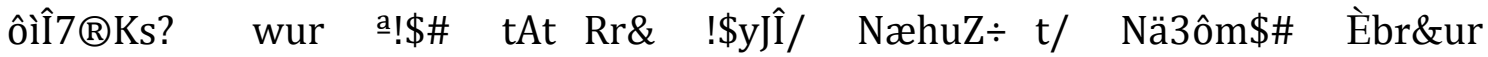

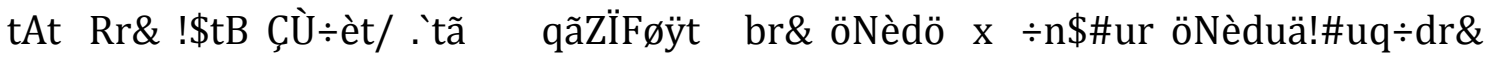

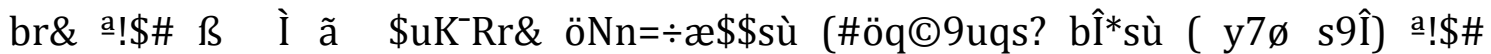

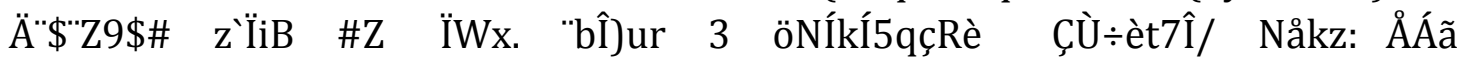

ÇíÒÈ tbqà)Å Å»xÿs9

Artinya: Dan hendaklah kamu memutuskan perkara di antara mereka menurut apa yang diturunkan Allah, dan janganlah kamu mengikuti hawa nafsu mereka. dan berhati-hatilah kamu terhadap mereka, supaya mereka tidak memalingkan kamu dari sebahagian apa yang Telah diturunkan Allah kepadamu. jika mereka berpaling (dari hukum yang Telah diturunkan Allah), Maka Ketahuilah bahwa Sesungguhnya Allah menghendaki akan menimpakan mushibah kepada mereka disebabkan sebahagian dosa-dosa mereka. dan Sesungguhnya kebanyakan manusia adalah orang-orang yang fasik. ${ }^{10}$

Dengan demikian, adalah keliru apabila manusia masih menganggap masalah seksual adalah masalah kotor, tabu, dan menjijikkan. Bahkan pendidikan seks dianggap tidak ada sangkut pautnya dengan ajaran Islam. Sebenarnya masalah seksual bukan hanya sekedar masalah biologis, melainkan lebih dari itu, dia memiliki keterpautan yang sangat erat dengan ajaran moral. Islampun telah mengajarkannya secara rinci.

Dalam surat Fathir ayat 11 Allah Swt berfirman:

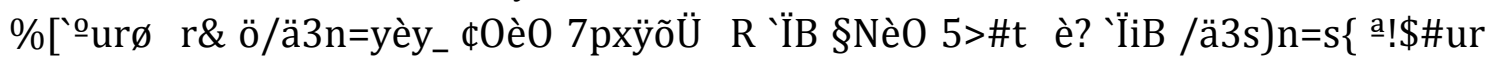
ã $\quad$ IJyèã \$tBur 4 3/4Ï̈mÏJù=İêI/ wÎ) ßì Òs? wur 4Ós \Ré\& ôÏB ã@ÏJøtrB \$tBur 4

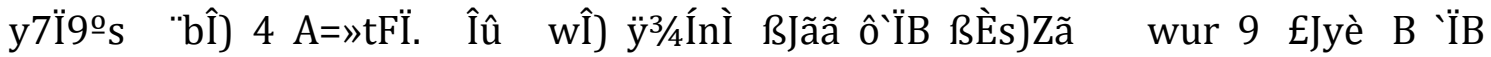

ÇÊÊÈ $\times \quad \AA_{j o} \quad$ «!\$\# n?tã Artinya: Dan Allah menciptakan kamu dari tanah Kemudian dari air mani, Kemudian dia menjadikan kamu berpasangan (laki-laki dan perempuan). dan tidak ada seorang perempuanpun mengandung dan tidak (pula) melahirkan melainkan dengan sepengetahuan-Nya. dan sekali-kali tidak dipanjangkan umur seorang yang berumur panjang dan tidak pula dikurangi umurnya, melainkan (sudah ditetapkan) dalam Kitab (Lauh mahfuzh). Sesungguhnya yang demikian itu bagi Allah adalah mudah (QS; Al-Fathir, ayat 11)

Pendidikan seks pada anak diawali dengan pengenalan identitas, yaitu laki-laki dan perempuan, dengan menunjukkan cirri-ciri yang bisa membedakan keduanya, misalnya dari segi fisik pada laki-laki otot lebih kencang, jantung, paru-paru, dan otak lebih berat daripada perempuan. Dan laki-laki mempunyai penis, sementara perempuan mempunyai vulva (vagina), dan payudara yang berkembang. Ini sesuai dengan fitrahnya perempuan yang digariskan Allah akan menjadi ibu yang akan melahirkan dan menyusui anaknya. Dan laki-laki akan menjadi seorang pemimpin baik di rumah tangganya dan atau di masyarakat. ${ }^{11}$ 
Baik laki-laki maupun perempuan masing-masing memiliki perbedaan terhadap yang lainnya. Perbedaan yang memisahkan itu justru meningkatkan hasrat yang menyatukan mereka. Karena masing-masing pihak justru menemukan kepuasan dan kelengkapan dari yang lainnya.

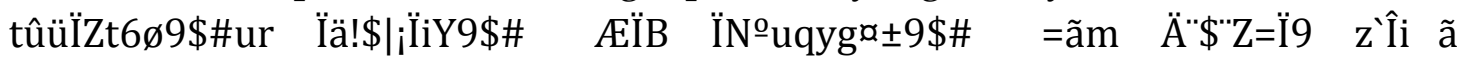

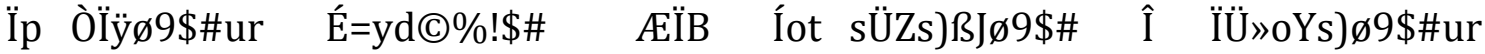

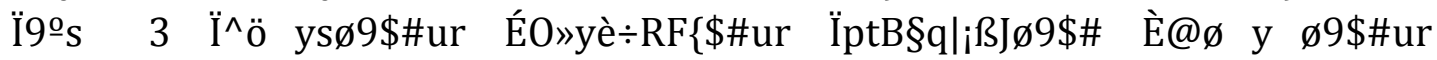
É>\$t«yJø9\$ ÚÆójãm 1/4çny Yİã a !\$\#ur ( \$u $\div \mathrm{R}$ 9\$ Ío4qu ysø9\$\# ßì»tFtB ÇẾİ

Artinya: Di jadikan indah pada pandangan manusia kecintaan kepada apa-apa yang diingini, yaitu: perempuan-perempuan, anak-anak, harta yang banyak, dari jenis emas, perak, kuda pilihan, binatang-binatang ternak dan sawah ladang. Itulah kesenangan hidup di dunia dan di sisi Allah-lah tempat kembali yang sebaik-baiknya (QS; Ali Imran ayat 14)

Dalam haditsnya Rasulullah bersabda: "Tiga hal dari dunia kalian ini menjadi kesukaanku yakni kaum perempuan, parfum, dan kesejukan mataku ketika shalat."

Allah menciptakan segala sesuatu itu berpasang-pasangan, dan manusia, berpasangan laki-laki dan perempuan. Adalah kodratnya bahwa manusia itu mempunyai kecendrungan kepada lawan jenisnya. Nabiyullah Rasulullah SAW, adalah manusia yang paling sempurna dan pria yang paling sempurna. Kecintaannya kepada kaum perempuan menunjukkan bahwa kesempurnaan keadaan manusia terkait dengan kecintaan kepada manusia lainnya, bukan semata-mata kecintaan kepada Tuhan. Secara lebih khusus hal ini menunjukkan bahwa kesempurnaan pria terletak pada kaum perempuan dan kesempurnaan kaum perempuan terletak pada kaum pria. ${ }^{12}$

Tetapi kecenderungan itu haruslah didasarkan kepada aturan yang sudah digariskan oleh Allah. Dalam hal ini adalah melalui perkawinan. Rasulullah bersabda: "Barangsiapa di antara kalian yang mampu menikah, maka menikahlah. Karena hal itu dapat menundukkan pandangan dan memelihara kemaluan. Namun bagi mereka yang tidak mampu, maka berpuasalah. Karena perbuatan tersebut dapat menjaganya dari perbuatan haram."

Kemudian dalam surah ar-Rum ayat 21 Allah SWt berfirman:

\%[ํurø r\& öNä3ÅjàÿRr\& ô ÏiB /ä3s9 t,n=y\{ ‘br\& ÿ3/4ÏIÏG»t \#uä ô ÏBur

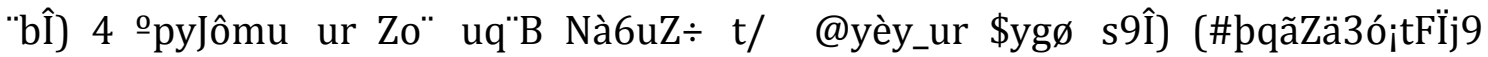
ÇËÊÈ tbrã (C)3xÿtGt 5Qöqs)Ïj9 ;M»t Uy y7Ï9ºs Îu

Artinya: Dan di antara tanda-tanda kekuasaan-Nya ialah Dia menciptakan untukmu istri-istri dari jenismu sendiri, supaya kamu cenderung dan merasa tenteram kepadanya, dan dijadikan-Nya di antaramu rasa kasih dan sayang. Sesungguhnya pada yang demikian itu benar-benar terdapat tanda-tanda bagi kaum yang berfikir.

Secara garis besar, perkawinan menghalalkan perbuatan seksual, dalam hal ini adalah hubungan seksual (persetubuhan) antara seorang laki-laki dan perempuan, yang jikalau tanpa adanya ijab kabul dalam pernikahan 
merupakan suatu perbuatan yang haram. Hubungan ini di dasarkan pada kasih sayang yang melahirkan perasaan tenteram antara satu dengan yang lainnya. Islam berusaha membangun ikatan yang sakral dengan tujuan untuk membentuk masyarakat yang bersih, suci, dan paripurna, yakni masyarakat yang jauh dari segala kehinaan dan kebusukan serta masyarakat yang diikat oleh jalinan kasih sayang, tidak takluk pada percekcokan, tidak dikuasai oleh para pelacur, dan sama sekali tidak merendahkan martabat perempuan. Karena antara suami dan istri menunjukkan bahwa masing-masing adalah setengah bagian yang membutuhkan setengah bagian yang lain untuk mempertahankan keberadaannya. ${ }^{13}$

Agar anak-anak terhindar dari penyimpangan-penyimpangan seks yang dapat merendahkan akal, fikiran dan akhlak mereka, maka pendidikan seks tersebut perlu dilakukan dengan cara-cara yang baik.

\section{Urgensi dan Tujuan Pendidikan Seks pada Anak}

Pendidikan seks penting untuk anak agar anak tidak kekurangan informasi tentang seks. Dengan sifat keingintahuannya seorang anak akan selalu mencari tahu segala sesuatu yang didengarnya dari pergaulannya seharihari. Masih untung sebetulnya jika si anak menanyakan hal tersebut kepada orang tuanya, daripada dapat pengajaran sebagian-sebagian dari orang lain yang mungkin tidak punya pengetahuan tentang itu. Apalagi masalah seks, orang cenderung membayangkannya sebagai masalah hubungan intim. Alangkah disayangkan kalau anak mendapat pengetahuannya dari orangorang yang tidak bertanggung jawab. Karena itu pendidikan seks diperlukan agar anak mengetahui fungsi organ seks, tanggung jawab yang ada padanya, halal haram berkaitan dengan organ seks dan panduan menghindari penyimpangan dalam perilaku seksual mereka sejak dini. ${ }^{14}$

Menurut Sofyan Sauri pendidikan seks itu penting terutama bagi remaja karena beberapa hal. Pertama, anak akan tumbuh menjadi remaja dan mereka belum paham tentang seks, sementara orang tua menganggap kalau membicarakan seks adalah hal yang tabu. Karena ketidakpahaman itu para remaja merasa tidak bertanggung jawab dengan seks atau kesehatan anatomi reproduksinya. Kedua, dari ketidakpahaman remaja tentang seks dan kesehatan anatomi reproduksinya, di lingkungan seosial masyarakat, hal lain ditawarkan hanya sebatas komoditi, seperti media-media yang menyajikan hal-hal yang bersifat pornografi, antara lain seperti VCD, majalah, internet, bahkan tayangan televisipun sudah mengarah ke hal-hal yang seperti itu. Dampak dari ketidakpahaman remaja tentang seks, banyak hal-hal negatif yang terjadi, seperti hubungan seks di luar nikah, kehamilan yang tidak diinginkan, penularan virus HIV, dan lain sebagainya. ${ }^{15}$

Tujuan pendidikan seks berbeda-beda sesuai usia perkembangan. Seperti pada usia balita, tujuannya adalah untuk memperkenalkan organ seks yang dimiliki, seperti menjelaskan anggota tubuh lainnya, termasuk menjelaskan fungsi serta cara melindunginya. Untuk usia sekolah mulai 6-10 
tahun bertujuan memahami perbedaan jenis kelamin (laki-laki dan perempuan), menginformasikan asal-usul manusia, membersihkan alat genital dengan benar agar terhindar dari kuman dan penyakit. ${ }^{16}$

Pada usia menjelang remaja, pendidikan seks bertujuan untuk menerangkan masa pubertas dan karakteristiknya, serta menerima perubahan dari bentuk tubuh. Berbeda halnya dengan pendidikan seks yang diberikan pada anak usia remaja, pendidikan seks berguna untuk memberi penjelasan mengenai perilaku seks yang merugikan (seperti seks bebas), menanamkan moral dan prinsip "say no" untuk seks pranikah serta membangun penerimaan terhadap diri sendiri.

Bahkan, pendidikan seks juga penting diberikan pada anak di usia pranikah untuk pembekalan pada pasangan yang ingin menikah tentang hubungan seks yang sehat dan tepat. Dan usia setelah menikah, pendidikan seks penting diberikan untuk memelihara pernikahan melalui hubungan seks yang berkualitas dan berguna untuk melepas ketegangan.

\section{Cara Mengajarkan Seks Pada Anak}

Pada prinsipnya, mengajarkan seks pada anak sama seperti memberikan imunisasi. Pengajaran ini akan merangsang tumbuhnya kekebalan tubuh anak terhadap kontaminasi seks yang tidak benar. Anak yang telah mendapatkan imunisasi seks dengan lengkap diharapkan akan memiliki kekebalan dan kontrol diri yang tinggi terhadap serangan virus seks yang jahat, misalnya pornografi, penyimpangan, atau penyalahgunaan seks. Sehingga nantinya tidak mudah terinfeksi perilaku seks yang tidak bertanggung jawab.

Pendidikan seks pada anak tidak bisa dilakukan secara instan, melalui tahap demi tahap sejak dini. Diajarkan mulai dari hal yang paling sederhana, dan jadikan sebagai satu kebiasaan sehari-hari. Tetapi sebelumnya yang harus dipersiapkan oleh orang tua adalah sikap mental orang tua, yaitu mengikis terlebih dahulu perasaan risih yang menetap di pikiran. Kemudian dilanjutkan dengan membangun komunikasi yang suportif (dimana orang tua membiasakan diri mendengar dan memahami anak tanpa memaksanya masuk ke dalam kerangka berfikir orang tua). Komunikasi suportif penting agar terjadi keterbukaan emosional anak kepada orang tua, menumbuhkan kepercayaan diri anak terhadap orang tua, juga diharapkan terciptanya dialog yang harmonis dan jujur di dalam keluarga, dan tentunya akan terjadi kedekatan dan solid antara anggota keluarga.

Ada beberapa hal yang harus dilakukan ketika mengajarkan seks pada anak $^{17}$ yaitu; 1) Bersikap jujur dan terbuka, artinya orang tua memberikan imformasi yang benar dan apa adanya. Karena ketidakjujuran atau menjawab asal-asalan hanya akan mengacaukan logika sehat si anak; 2) Step by step, pastikan mengajari anak selangkah demi selangkah, sejalan dengan pertanyaan yang mereka ajukan. Sesuaikan penyampaian dengan tingkat pemahaman si anak; 3) Belajar untuk santai, wajar dan bersikap biasa-biasa saja. Jangan membesar-besarkan masalah, lantas menganggap seks topic yang berat, 
usahakan rileks, dan jaga intonasi ketika menjawab cecaran pertanyaan anak. Hindarkan perasaan risih, jengah dan takut. Anggap saja ini sama dengan menjelaskan soal hujan, soal bulan, bintang, atau soal memasak dan lain-lain. Disarankan orang tua terlebih dahulu melepaskan diri dari semua persepsi seks dewasa yang erotis dan mesum; 4) Hindari kemarahan yang negatif, yakni marah dan menolak pertanyaan anak melalui hardikan dan umpatan kata-kata kasar, hindari juga perkataan bahwa seks itu kotor, dosa, dan tak pantas untuk dibicarakan, karena ini hanya akan memicu persepsi negatif tentang seks pada anak yang akhirnya akan menjadikan pemahaman yang keliru tentang seks.

\section{Tahapan Umur untuk pengajaran Seks pada Anak}

Ada beberapa tahapan untuk mengajarkan seks pada anak berdasarkan tingkatan umur. ${ }^{18}$

Pertama, anak di bawah umur tujuh tahun yang harus diperkenalkan adalah pengenalan identitas antara laki-laki. Membiasakan beberapa kosa kata seperti vagina, testis, penis, dan payudara. Hindari mengucapkannya dengan perasaan risih dan sambil berbisik, bersikaplah santai dan biasa seperti orang tua menyebut anggota tubuh lainnya seperti mulut, lidah, telinga dan lain-lain. Tidak perlu merasa khawatir dengan pertanyaan seks anak, karena mereka tidak akan menghabiskan waktunya setiap hari untuk mengutak atik soal seks, bagi mereka sama seperti menanyakan masalah pesawat terbang, matahari, hujan, dan lain-lainnya.

Kedua, untuk anak pra remaja yaitu yang berusia 7-10 tahun, maka pembekalan seksual dilakukan dengan memberitahukan anak fakta-fakta seputar reproduksi, misalnya memberikan penjelasan tentang perkawinan, konsepsi dan persalinan, baik pada manusia ataupun makhluk hidup lainnya. Akan lebih mudah jika orang tua merujuk pada aktivitas seksual spesies lain seperti anjing, kucing, ayam, ikan dan lain-lain.

Ketiga, dengan pendekatan ilmiah dan biologis angkat dan jelaskan soal reproduksi dan aktivitas seksual manusia, mulai dari persenggamaan hingga bagaimana terjadinya proses kelahiran. Bantu juga anak untuk lebih mengenal dan menghargai seluruh anggota tubuhnya termasuk organ seks dan organ reproduksinya. Beri pemahaman yang benar tentang institusi keluarga, tujuan, dan kewajiban selaku anggota keluarga yang baik dan terhormat, serta pembekalan lain seperti kesetiaan, cinta, kasih sayang, dan kewajiban untuk saling menghormati dan menghargai sesama manusia. Dan yang penting beri penjelasan tuntas seputar menarche bagi anak perempuan dan mimpi basah bagi anak laki-laki.

Keempat, untuk remaja berusia 11-14 tahun. Pengajaran seksualitas ditekankan pada antisipasi perubahan yang terjadi selama masa remaja terkait dengan aktifnya hormon seksualnya, perbedaan yang dialami oleh laki-laki dan perempuan, perbedaan percepatan perkembangan dan pertumbuhan, bagaimana mencapai kematangan seksual, dan pemilihan perilaku seksual. Silahkan saja di jawab jika anak menanyakan tentang keberagaman perilaku 
seksual seperti gay, lesbian, waria, exhibitionism, pedophilia, dan lain-lain. Yang penting hindari mengimformasikan seks secara berbisik-bisik dengan raut wajah gelisah dan menakut-nakuti anak.

Kelima, remaja di atas 15 tahun, diharapkan sudah benar-benar memiliki pengetahuan seks yang utuh, lengkap dan benar serta memahami sesuai norma yang dianut keluarga. Pengajaran seksual pada anak usia ini dilakukan dengan diskusi tertutup berdasarkan kesamaan jender demi menghindar perasaan rikuh dan malu pada anak. Diskusi dilakukan dengan obrolan santai sambil mendiskusikan relasi laki-laki dan perempuan, aspek percintaan lawan jenis, kesepakatan tentang pacaran, kebijaksanaan keluarga menanggapi hubungan seks pranikah, seluk beluk peting, persenggamaan, kontrasepsi, pornografi, penyimpangan seks, dan penyakit menular seksual. Dorong anak memegang teguh prinsip dan standar moral yang dimilikinya meskipun itu bertentangan dengan prinsip teman-temannya.

\section{SIMPULAN}

Pendidikan seks penting bagi anak agar anak sebagai upaya preventif atau mencegah anak melakukan segala macam penyalahgunaan seks, yang dalam Islam adalah hal yang terlarang. Diharapkan dengan pendidikan seks yang baik, anak anak-anak akan tumbuh menjadi manusia dewasa yang unggul dan generasi yang lebih berkualitas.

Pendidikan seks dilakukan secara bertahap sesuai tahapan umur, dan perkembangan anak baik secara biologis, psikologis, ataupun sosialnya. Dalam hal ini orang tua harus bisa berkomunikasi secara suportif, sehingga terjalin kedekatan dan keterbukaan anak dengan orang tua dalam segala hal. Yang penting dalam mengajarkan seks pada anak, adalah sikap mental orang tua, yaitu mengikis habis perasaan risih, malu, jengah, dan menganggap masalah seks sesuatu yang tabu dan hanya seputar masalah hubungan intim.

\section{Endnotes:}

1 Yasmira Hana. 2009. Ayo Ajarkan Anak Seks. Penerbit PT Elex Media Komputindo. Jakarta hlm. 2

2 Dini Oktaufik. 2010. Pentingnya Pendidikan Seks Pada Anak Kebutuhan Khusus. http:/ / www.waspada.co.id

3 Sani B. Hermawan. Op.Cit.

$4 \quad$ Ibid.

5 Nasaruddin Umar. 2010. Argument Kesetaraan Jender Perspektif Al-Quran. Penerbit Dian Rakyat. Jakarta. hlm. 31.

6 Yasmira Hana. Op.Cit, hlm. 203.

$7 \quad$ Ibid.

$8 \quad$ Ibid, hlm. 91.

9 Ibid, hlm. 86.

10 Al-Quran dan Terjemahannya.

11 Edi Warsidi. 2006. Pentingnya Pendidikan Agama Sejak Dini. Penerbit Pustaka Madani Bandung. hlm. 45. 
12 Sachiko Murata. 1996. The Tao of Islam. Kitab Rujukan tentang Relasi Gender dalam Kosmologi dan Teologi Islam. Penerbit Mizan. hlm. 246.

13 Khalid As-Sayyid 'Abdul 'Al. 2005. Seni Bercinta Dalam Islam. Penerbit Mujahid Press. hlm. 18.

14 Akram Ridho. 2010. Pentingnya Pendidikan Seks Usia Dini. http://www.waspada.co.id

15 Sofyan Sauri. 2007. Pentingnya Sex Education. http://www.waspada.co.id

16 Sani B. Hermawan. 2010. Pentingnya Pendidikan Seks pada Anak. http:/ / www.waspada.co.id

17 Yasmira Hana. Op.Cit. hlm. 61-65

18 Ibid. hlm. 76

\section{DAFTAR PUSTAKA}

Akram Ridho. 2010. Pentingnya Pendidikan Seks Usia Dini, http://www.waspada.co.id

Al-Quran dan Terjemahannya.

Dini Oktaufik. 2010. Pentingnya Pendidikan Seks Pada Anak Kebutuhan Khusus.

http:/ / www.waspada.co.id

Edi Warsidi. 2006. Pentingnya Pendidikan Agama Sejak Dini, Penerbit Pustaka Madani Bandung

Khalid As-Sayyid 'Abdul 'Al. 2005. Seni Bercinta Dalam Islam, Penerbit Mujahid Press

Nasaruddin Umar. 2010. Argument Kesetaraan Jender Perspektif Al-Quran, Penerbit Dian Rakyat. Jakarta

Sachiko Murata. 1996. The Tao of Islam. Kitab Rujukan tentang Relasi Gender dalam Kosmologi dan Teologi Islam, Penerbit Mizan, Bandung

Sani B. Hermawan. 2010. Pentingnya Pendidikan Seks pada Anak, http:/ / www.waspada.co.id

Sofyan Sauri. 2007. Pentingnya Sex Education. http://www. waspada. co.id

Yasmira Hana. 2009. Ayo Ajarkan Anak Seks, Penerbit PT Elex Media Komputindo, Jakarta 